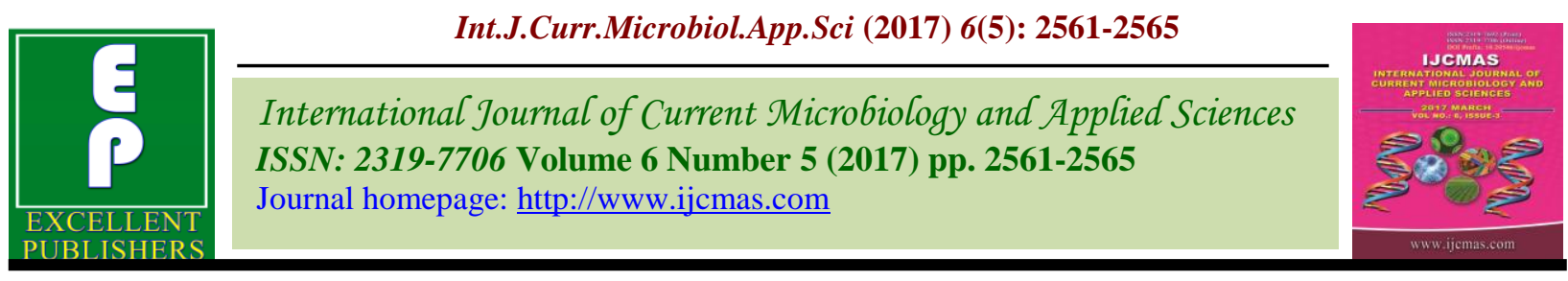

Original Research Article

https://doi.org/10.20546/ijcmas.2017.603.290

\title{
A Study on Fish Diversity in a Fresh Water Lake in Tamil Nadu, India
}

\author{
R. Anbalagan and R. Sivakami* \\ P.G \& Research Department of Zoology, Arignar Anna Govt. Arts College, \\ Musiri - 621 211, Tamil Nadu, India \\ *Corresponding author
}

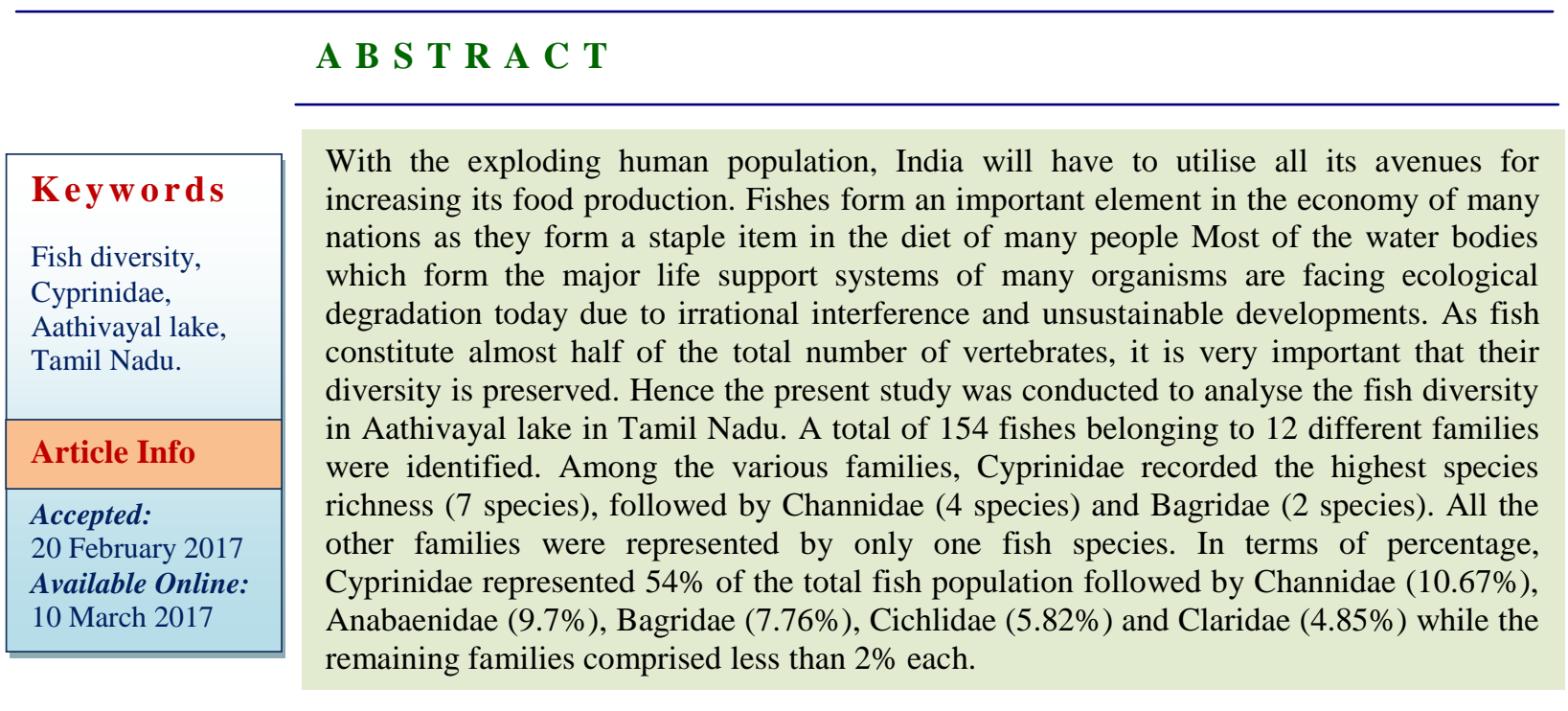

\section{Introduction}

With the exploding human population, India will have to utilise all its avenues for increasing its food production. Fishes form an important element in the economy of many nations as they form a staple item in the diet of many people (Shukla and Singh, 2013). Hence, fish farming will play a vital role as it is a source of cheap animal protein in human diet in the coming years (Singh et al., 1994). However, most of the water bodies which form the major life support systems of many organisms are facing ecological degradation today due to irrational interference and unsustainable developments (Prasad et al., 2009). According to Jenkins (2003), freshwater biodiversity has declined faster than either marine or terrestrial diversity over the past 30 years. Species diversity is likely to be further reduced due to increased temperatures, reduced precipitation and increased withdrawal of water for agriculture and other uses (Vorosmarty et al., 2000; Alcamo et al., 2003). Human activities have resulted in drastic degradation of aquatic resources resulting in the alteration of structure and function. As fish constitute almost half of the total number of vertebrates it is very important that their diversity is preserved. Hence the present study was conducted to analyse the fish diversity in Aathivayal lake. 


\section{Materials and Methods}

\section{Data Collection and Analysis}

Fish sampling was performed in five sampling sites during the period from January 2016 to December 2016 with the help of local fishermen using different types on nets namely gill nets, cast nets and dragnets. Photographs were taken prior to preservation as formalin decolorizes the fish. Fishes brought to the laboratory were fixed in this solution in separate jars according to the size of species. Smaller fishes were directly placed in the formalin solution while larger fishes were given an incision on the abdomen before they were fixed. The fishes were labeled giving serial numbers, exact site from where collected, date of collection and the local name of fish used in this region. Identification of fishes was carried out by following Talwar and Jhingran (1991).

Water samples were collected between 8 and 9 am and transported to the laboratory immediately for further analyses. Water temperature was measured at the time of sampling using mercury thermometer while $\mathrm{pH}$ was measured with standard $\mathrm{pH}$ meter. Other parameters were analyzed in the laboratory according to the methods suggested by American Public Health Association (APHA, 1992).

Fish were subjected to diversity analyses using different indices like Shannon - Weiner index (H) (1963), Simpson Dominance index (D) and Simpson index of diversity (I-D) (1949).

Shannon - Weiner index was calculated by using the formula:

$\mathrm{H}=\Sigma_{\mathrm{p}_{\mathrm{i}}} \log 2 \mathrm{P}_{\mathrm{i}}$

where
$\mathrm{H}=$ Shannon-Weiner index

$\mathrm{Pi}=\mathrm{ni} / \mathrm{N}$

$\mathrm{ni}=$ Number of individuals of each species in the sample

$\mathrm{N}=$ Total number of individuals of all species in the sample.

Abundance of fish population was calculated by the sum of all available fishes in different sites. Species richness was simply estimated by the variety of fish species in five different sites.

\section{Simpson's Diversity Indices}

Simpson's diversity index is a measure of diversity. In ecology, it is often used to quantify the biodiversity of a habitat. It takes into account the number of species present, as well as the abundance of each species.

Simpson's index of dominance was calculated by using the formula:

$$
D=\Sigma \frac{n i(n i-1)}{N(N-1)}
$$

where,

$\mathrm{ni}=$ the total number of individuals of a particular species.

$\mathrm{N}=$ the total number of individuals of all species.

Simpson's index of diversity $1=\mathrm{D}$

\section{Results and Discussion}

Details of the various species of fish that were caught in the system are presented in Table-1a $\& b$. As evident from the Table, a total of 154 fishes belonging to 12 different families were identified. Among the various families, Cyprinidae recorded the highest species richness ( 7 species), followed by Channidae (4 species) and Bagridae (2 species). All the other families were represented by only one fish species. 
Table.1a Fish Diversity of Aathivayal Lake

\begin{tabular}{|c|c|c|}
\hline S. No. & Family & Percentage \\
\hline \multicolumn{3}{|c|}{ Cyprinidae } \\
\hline 1. & Catla catla (Hamilton Buchaman) & 18.0 \\
\hline 2. & Cirrhinus mrigala & 9.0 \\
\hline 3. & Cirrhinus reba & 4.0 \\
\hline 4. & Ctenopharyngodon idella & 5.0 \\
\hline 5. & Cyprinus carpio & 5.0 \\
\hline 6. & Hypophthalmicthys molitrix & 6.0 \\
\hline 7. & Labeo rohita & 8.0 \\
\hline \multicolumn{3}{|c|}{ Bagridae } \\
\hline 8. & Mystus carasius & 2.0 \\
\hline 9. & Mystus vittatus & 6.0 \\
\hline \multicolumn{3}{|c|}{ Channidae } \\
\hline 10. & Channa marulius & 2.0 \\
\hline 11. & Channa punctatus & 7.0 \\
\hline 12. & Channa striatus & 2.0 \\
\hline 13. & Notopterus notopterus & 1.0 \\
\hline \multicolumn{3}{|c|}{ Siluridae } \\
\hline 14. & Ompok bimaculatus & 1.0 \\
\hline \multicolumn{3}{|c|}{ Anabantidae } \\
\hline 15. & Anabas testudineus & 10.0 \\
\hline \multicolumn{3}{|c|}{ Anguillidae } \\
\hline 16. & Anguilla bengalensis & 1.0 \\
\hline \multicolumn{3}{|c|}{ Aplocheilidae } \\
\hline 17 & Aplocheilus lineatus & 2.0 \\
\hline \multicolumn{3}{|c|}{ Clariidae } \\
\hline 18. & Clarias batrachus & 5.0 \\
\hline \multicolumn{3}{|c|}{ Gobiidae } \\
\hline 19. & Glossogobius giuris & 1.0 \\
\hline \multicolumn{3}{|c|}{ Cichlidae } \\
\hline 20. & Oreochromis mossambicus & 6.0 \\
\hline \multicolumn{3}{|c|}{ Mugilidae } \\
\hline 21. & Rhinomugil corsula & 2.0 \\
\hline \multicolumn{3}{|c|}{ Amphipnoidae } \\
\hline 22. & Amphipnous & 1.0 \\
\hline
\end{tabular}

Table.1b Fish Diversity Indices

\begin{tabular}{|l|c|}
\hline Species richness & 19 \\
\hline Abundance number & 154 \\
\hline Shanan weiners index & 0.009 \\
\hline Simpson's dominace index & 0.042 \\
\hline Simpson's diversity index & 0.84 \\
\hline
\end{tabular}


In terms of percentage, Cyprinidae represented $54 \%$ of the total fish population followed by Channidae (10.67\%), Anabaenidae (9.7\%), Bagridae (7.76\%), Cichlidae (5.82\%) and Claridae (4.85\%) while the remaining families comprised less than $2 \%$ each.

A family wise comparison reveals that in Cyprinidae, among the seven species that were recorded, the most dominant one in terms of number was Catla catla followed by Cirrhinus mrigala. Among Channidae, the most dominant species was Channa punctatus and in Bagridae it was Mystus carassius.

Baillie and Groombridge (1996) suggested that according to IUCN Redlist of threatened animals, $20 \%$ were freshwater fishes. Literature reveals that abiotic and biotic factors play an important role in fish diversity in freshwater ecosystems. While Sivakami et al., (2015) reported that physico-chemical characteristics like $\mathrm{pH}$ and dissolved oxygen are key habitat features which can be correlated to fish diversity, Sharma and Gupta (1994) after studying the effect of temperature on the growth of fishes reported that the ideal temperature for their growth was between 14.5 and $38.6{ }^{\circ} \mathrm{C}$. In the present study, the water temperature was found to range between 20 and $28^{\circ} \mathrm{C}$ which appears favourable for growth of fish. Jhingran (1983) suggested that the ideal $\mathrm{pH}$ for fish growth was between 7 and 9 units. In the present study also, the $\mathrm{pH}$ averaged 7 to 8.5 units which is favourable for fish growth. Welch (1952) while analyzing the physico-chemical variables of more than a thousand inland bodies in US reported that DO levels of less than $3 \mathrm{mg} / \mathrm{l}$ should be regarded as hazardous to lethal under average conditions and that 5 $\mathrm{mg} / \mathrm{l}$ or more should be present in waters if conditions are to be favourable for fish culture. A perusal of the DO levels in the present study reveals that DO levels were always above $3 \mathrm{mg} / \mathrm{l}$. Earlier, similar reports were also suggested by Senthil et al., (2012), Shukla and Singh (2013) and Sivakami et al., (2014). In addition, Jhingran (1983) also suggested that high siltation can cause an adverse effect on fish productivity by interfering with its respiratory system while Prasad et al., (2009) suggested that increased BOD values can decrease DO levels and affect fish productivity.

Thus it is imperative to know the factors which control the quality of life in a system for the sustenance and maintenance of fish diversity. According to Shukla and Singh (2013) the best approach towards the conservation of a species is to disseminate information, education and awareness about the danger and extinction of species as preservation is not only better but also is cheaper than looking for ways for recalling the lost species.

\section{References}

Alcamo, J., Doll, P. and Henrichs, T. (2003). Global estimates of water withdrawals and availability under current and future 'business-as-usual' conditions. Hydrological Sciences Journal, 48: 317-337.

APHA (1992). Standard methods for the examination of water and wastewater. American Public Health Association, Washington, USA.

Ballie and Growbridge, B. (1996). IUCN red list of threatened animals. IUCN, Washington DC, p. 28.

Jenkins, M. (2003). Prospects for Biodiversity. Science, 302: 1175-1177.

Jhingran, V. G. (1983). Fish and Fisheries of India. Hindustan Publishing Corporation, New Delhi, p. 460.

Prasad, D., Venkataramana, G. V. and Thomas, M. (2009). Fish diversity and its conservation in major wetlands of 
Mysore. Journal of Environmental Biology, 30: 713-718.

Senthil Murugan, A. and Prabaharan, C. (2012). Fish Diversity in relation to Physico-chemical characterstics of Kamala Basin of Darbhanga District, Bihar, India. International journal of Pharmaceutical \& Biological Archives, 3: 211-217.

Sharma, L. L. and Gupta, M. C. (1994). Some aspects of limnology of Awarchand reservoir, Rajasthan. Physical Parameters, Pollution Research, 13: 16-179.

Shukla, P. and Singh, A. (2013). Distribution and diversity of freshwater fishes in Aami River, Gorakhpur, India. Advances Biological Research, 7: 2631.

Singh, V. N., Kumar, V. and Singh, G. P. (1994). Qualitative and quantitative study of benthic fauna of Kararia lake of Motihari, Bihar, India. Journal of Freshwater Biology, 6: 21-25.

Sivakami, R., Sirajunisa, V., Abdul Kader, K. and Prem Kishore, G. (2015). Fish Diversity and its Conservation in Uyyakkondan Channel, Tiruchirappalli District, Tamil Nadu. Intenational Journal of Zoological Research, 5: 2732.

Talwar, P. K. and Jhingran, V. G. (1991). Inland Fishes of India and Adjacent Countries. Oxford and IBH Publishing Co., New Delhi. 112 - 116.

Vorosmarty, C., Green, J. P. and Salisbury, J. (2000). Water system group. A Global Hydrology Research Group. Science, 289: 284-288.

Welch, P. S. (1952). Limnological Methods. McGraw-Hill Book Co. Inc., New Delhi. p. 280.

\section{How to cite this article:}

Anbalagan, R., and Sivakami, R. 2017. A Study on Fish Diversity in a Fresh Water Lake in Tamil Nadu, India. Int.J.Curr.Microbiol.App.Sci. 6(5): 2561-2565. doi: https://doi.org/10.20546/ijcmas.2017.603.290 